\title{
Suplantaciones de mujeres en la narrativa hispanohebrea: Misoginia y fealdad ${ }^{1}$
}

Impersonations of women in the Hispano-Hebrew narrative: Misogyny and ugliness

\author{
Paulina Lorca \\ Universidad Alberto Hurtado / Universidad Gabriela Mistral \\ Paulinalorca@gmail.com
}

"Pero la fealdad en un hombre no importa demasiado.

La fealdad en una mujer se convierte en su vida"

Joyce Carol Oates

"Escribo desde la fealdad, y para las feas, las viejas, [...] todas las excluidas del gran mercado de la buena chica".

Virginie Despentes

\section{Resumen}

Los estudios sobre las representaciones femeninas en la literatura medieval suelen basarse en dos estereotipos: las mujeres que cumplen con el rol modélico y aquellas que encarnan diversos vicios, dando cuenta de la corriente misógina de la época. La presente investigación, centrada en el ámbito hispanohebreo, busca analizar las suplantaciones ideadas y realizadas por mujeres en dos textos narrativos del siglo XIII, discutiendo cómo se configuran los personajes femeninos, si acaso estos engaños refuerzan mecanismos misóginos y la forma en que se construyen otros estereotipos en torno a las mujeres, específicamente, el de las mujeres feas, velludas y bestiales.

Palabras clave: Misoginia - Suplantaciones - Harizi - Ibn Shabbetay - Fealdad

\begin{abstract}
${ }^{1}$ Este artículo se basa en mi tesis doctoral leída en la Universidad de Granada durante 2017.

Cuadernos Judaicos ISSN: 0718-8749


Studies on female representations in medieval literature tend to be based on two stereotypes: women who fulfill the role model and those who embody various vices, showing the misogyny of the time. This article focuses on Hispano-Hebrew Literature, analyzing the impersonations made by women in two narrative texts of the thirteenth century. The aim is to discuss how the female characters are configured, if perhaps these deceptions reinforce misogynistic mechanisms and the way in which other stereotypes about women are constructed, specifically, that of ugly, hairy and bestial women.

Keywords: Misogyny - Impersonations - Harizi - Ibn Shabbetai - Ugliness

\section{Introducción}

Es por todos sabido que la literatura medieval tendió a representar figuras de mujeres que respondían a dos extremos: el modelo y el vicio, es decir, "buenas y malas mujeres" (Haro, 1995, p. 458). En un extremo, la corriente mariana y el culto a la Virgen María; en otro, Eva, la imagen de mujer y madre de la Humanidad que arrastra al pecado. Ambos polos ejercieron su influencia en las representaciones femeninas de la literatura medieval.

Por una parte, hallamos el rol de mujer buena en la figura de Jimena en el Poema de Mío Cid. A lo largo del texto se destaca que es piadosa, honrada, leal a su esposo y que está dispuesta a seguir las decisiones que él toma. A pesar de ello, sus apariciones son escasas y cuando tiene la palabra, lo hace para hablar sobre su esposo. En general, las mujeres de la épica española tienden a ser "mujeres objetos de alianzas" (Victorio, 1986, p. 77) que gravitan en torno al personaje masculino, sobre el que gira la acción principal.

También ejemplar resulta el culto mariano expresado en los Milagros de Nuestra Señora de Gonzalo de Berceo, que plasma un modelo de Madre universal y fémina perfecta al que las mujeres deben aspirar. No hay lugar acá para los defectos, la mala conducta o cualquier actividad que separe a las mujeres de este estereotipo. 
Por el contrario, en consonancia con los discursos eclesiásticos de la época y los postulados de Aristóteles, quien "asocia lo femenino a la materia y el intelecto al hombre" (Olalla, 2002, p. 96), se produce en los siglos XIII y XIV una cuantiosa literatura misógina, que advierte sobre los vicios de las mujeres, siendo supuestamente la lujuria ${ }^{2}$ su principal pecado capital. De ellas se dice que conspiran en grupo en contra de sus maridos y que manejan los conocimientos de ciencias ocultas ${ }^{3}$, a la vez que poseen una "compulsiva, copiosa y excitante habladuría" (Louzada, 2010, p. 81), entre otras acusaciones. Esta corriente misógina ha quedado de manifiesto en textos como el Spill de Jaume Roig ${ }^{4}$ y el Corbacho de Giovanni Bocaccio, así como en géneros como la mala cansó provenzal ${ }^{5}$ y el maldit catalán.

Si bien estas dos corrientes aparecen profusamente en la literatura medieval, también hay que detenerse en otros textos que nos permiten vislumbrar la presencia de mujeres que fingen ser aquello que no son, con todo lo que conlleva mentir sobre las identidades. Se trata de dos obras narrativas hispanohebreas del siglo XIII, a saber: "El matrimonio" (“Ha-niśśu 'im”) de Yehudah ben Šelomoh al-Harizi y La ofrenda de Judá el misógino (Minhat Yehudah śone ha-Našim) de Yehudah ibn Šabbetay. En estos dos relatos las mujeres usan el engaño para escarmentar a los varones, aunque también su presencia es usada por los autores para plasmar otros estereotipos, como el de mujeres feas y, por ende, peligrosas. Esto se estudiará a continuación.

\section{2. "El matrimonio" de Yehudah ben Šelomoh al-Harizi}

El primer relato que se analiza es El matrimonio (“Ha-niśśs 'im”) y que forma parte del Tahkemoni $^{6}$, compuesto por Yehudah ben Šelomoh al-Harizi ${ }^{7}$ (1170-1230). Es una obra que consta de cincuenta relatos y que tiene como protagonista a un pícaro -que en este

\footnotetext{
${ }^{2}$ Véase Haro, 1995, p. 469 y Duby, 1998, p. 17.

${ }^{3}$ Véase Psaki, 2003, p.2.

${ }^{4}$ Sobre el entorno literario de Jaume Roig y su posible relación con la literatura hispanohebrea, véase Wacks (2007).

${ }^{5}$ Véase Archer y Riquer, 1998, p. 13.

${ }^{6}$ Se ha prescindido de las citas en hebreo para facilitar la comprensión del lector hispanohablante. La edición en hebreo se halla editada por Yahalom y Katsumata (2010).

7 Aunque se desconoce si provenía de al-Andalus o de la España cristiana, habría viajado por diversas ciudades de la Península ibérica y la Provenza y realizado - por encargo de varios mecenas- labores de traducción. Véase Sáenz-Badillos y Targarona 133. Sobre las diversas teorías sobre su origen, véase Decter, 2007, p. 126. Sobre la vida de al-Harizi y sus viajes, cfr. Tanenbaum, 2002, pp. 195-200.
} 
caso se llama Heber- que asombra al lector por su astucia, a la vez que deambula por diversos lugares. Junto a él aparece el narrador personaje que es amigo del pícaro, en este caso, llamado Heman el esrajita ${ }^{8}$.

El relato El matrimonio comienza cuando Heman, el narrador personaje, se encuentra con Heber, el protagonista. El narrador le dice a este que descanse, que debería asentarse en el lugar y tomar una esposa. Heber responde que ha prometido nunca más volver a caer "en las redes de la mujer" (Al-Harizi, 2010, p. 86), dando inicio a la historia.

Heber relata que deambulaba por la ciudad pensando en que debería dejar la soltería y conseguir una esposa. Mientras meditaba sobre esto conoce a una mujer vieja, horrible y perversa, a la que llama "satanesa" (Al-Ḥarizi, 2010, p. 87). Sin embargo, el aspecto que más destaca de esta mujer es su manera de hablar, tanto así que el protagonista señala que "el néctar se albergaba en su lengua y el veneno [...] se escondía en su garganta" (87).

Esta mujer -que nunca revela su nombre- representa la figura de la alcahueta, caracterizada por sus habilidades comunicativas, su astucia, seguridad y la influencia que ejerce en el protagonista, a quien adula y finalmente convence para que elija una mujer y forme una familia. Ella se muestra en todo momento dispuesta conseguir una esposa para Heber, siempre y cuando él le dé dinero.

La alcahueta de El matrimonio es hábil con sus palabras y describe a la futura novia siguiendo las convenciones medievales que aparecen en tratados retóricos como el Ars Versificatoria de Mateo de Vendôme: la descripción física sigue un orden de la cabeza a los pies $^{9}$, a la usanza latina. Además, se emplean figuras que son recurrentes en la literatura del Medioevo. Por ejemplo, se señala que la joven tiene ojos de gacela ${ }^{10}$, que

\footnotetext{
${ }^{8}$ Sobre la figura de un tal Heman en la Biblia, véase Hamilton, 2007, p. 72.

${ }^{9}$ Véase Salvatierra, 2013, p. 607. Para ahondar en las descripciones sobre las mujeres bellas en la literatura medieval, véase Ziolkowski (1984).

${ }^{10}$ En torno a esto, al-Sarif al Taliq (961-1009), poeta omeya de al-Andalus, dirá: "Hechiza el parpadeo de esta nívea gacela” (En Reina, 2007, p. 130).
} 
sus dientes son como zafiros ${ }^{11}$ y que irradia luz de su cuerpo ${ }^{12}$, solo por nombrar algunos aspectos.

Con la semblanza que se hace de la prometida, Heber se enamora y acepta la propuesta de la anciana: "se dejó arrastrar mi corazón por la dulzura de su discurso, quedó prendido por los lazos de su conjuro" (Al-Ḥarizi, 2010, p. 87).

Lo interesante de este relato es que el engaño se formula precisamente a partir de la palabra. Aquí no hay una presencia física ni una corporalidad tangible, sino que la identidad de la supuesta novia se va creando a partir de idealizaciones, falsos retratos y expectativas.

El problema radica en que al finalizar la celebración, Heber puede finalmente ver a su esposa que lleva un velo. ${ }^{13} \mathrm{Al}$ quitárselo, se da cuenta de que se trata de una mujer vieja y que todo ha sido un engaño. La descripción que se hace de la mujer llama la atención por alejarse del canon de belleza convencional y poner énfasis en su pelo encanecido, sus facciones avinagradas y su tono oscuro de piel.

Posteriormente, la esposa paga por algo que ella no ha cometido: recordemos que quien ha mentido sobre cómo es la novia es precisamente la alcahueta. Heber proyecta en su esposa toda la rabia que siente por el engaño. A esto hay que sumar el hecho de que su mujer, además de no ser bella, es pobre: solo posee unos paños raídos, unos trozos de utensilios y un par de platos, entre otras cosas. Esto provoca que Heber maldiga su mujer en una de las invectivas más violentas del Tahkemoni y de la literatura medieval en general: "Felices serían los que te engendraron / si hubieran muerto antes de darte la vida. / ¡Ojalá tu madre hubiera sido estéril!” (Al-Harizi, 2010, p. 90).

Al-Harizi relaciona a la mujer con elementos destructivos: sus ojos son un horno humeante, su boca es un sepulcro desde donde sale un viento huracanado, sus dientes

\footnotetext{
${ }^{11}$ La imagen del zafiro asociado a los dientes es algo más inusual, ya que para esto se tiende a emplear la imagen de las perlas, aunque de igual manera se transmite la idea de que la sonrisa descrita brilla.

${ }^{12}$ A modo de ejemplo, Dante Alighieri señala en un poema: "de mi dama procede / tan noble luz que cuando aparece / se ven cosas que nadie contaría" (En Alvar, 1984, p. 73).

${ }^{13}$ Sobre el uso del velo en las nupcias judías, v. Bloch 1980, p. 31.
} 
son una trituradora y en su vientre transforma la comida en ponzoña. Esta mujer resulta entonces peligrosa para el hombre, quien la ve como una amenaza.

Si antes habíamos presenciado la violencia verbal del protagonista, hacia el fin del relato aparece la violencia física: "Cogí entonces tres bastones en mis manos en plena noche, amordacé su boca con el vestido y rompí los tres bastones sobre sus espaldas, hasta que borbotó sangre por su boca. Desgarré todas sus carnes” (Al-Harizi, 2010, p. 91).

Este tipo de imágenes no debió sorprender al público medieval, habituado a las escenas de violencia de género, específicamente por parte de los maridos hacia sus esposas. Basta recordar el triste episodio de las hijas del Cid siendo golpeadas y abusadas por sus maridos en el robledal de Corpes. Escenas similares hallamos, por ejemplo, en la octava jornada de El Decamerón, en donde Calandrino golpea a su mujer hasta que "no le dejó cabello en la cabeza, ni hueso que no le doliese, sin que le valiera, a la desdichada, con los brazos cruzados pedirle clemencia" (Boccaccio, 1982, p. 442). Lo mismo sucede en los Cuentos de Canterbury, en donde la comadre de Bath ${ }^{14}$ relata que su marido la golpea: "de un brinco se revolvió, cual salvaje león, y me propinó tal manotazo en la cabeza, que me desplomé como muerta en el suelo" (Chaucer, 2011, p. 217). Incluso, aparece como una descripción de lo que ocurría a las mujeres en la Edad Media, tal como relata Derechura a la protagonista en La ciudad de las damas:

¡A cuántas mujeres podemos ver, y tú conoces algunas, querida Cristina que por culpa de la crueldad de un marido desgastan sus vidas en la desgracia [...] ¡Dios mío, cómo les pegan, a todas horas y sin razón! ¡Cuántas humillaciones, ataques, ofensas, injurias tienen que aguantar unas mujeres leales, sin gritar siquiera para pedir ayuda! Piensa en todas esas mujeres que pasan hambre y se mueren de pena en unas casas llenas de hijos, mientras sus maridos se enfrascan y andan vagando por todos los burdeles y tabernas de la ciudad. Y todavía, cuando ellos vuelven, ellas pueden recibir como cena unos buenos golpes. (Pizán, 2013, p. 123)

\footnotetext{
${ }^{14}$ Un interesante análisis sobre la violencia en este relato puede hallarse en Leech (2002).
} 
Las mujeres ante este tipo de violencia bastante poco podían hacer, ya que en el Medioevo se consentía que los maridos quisieran someter y disciplinar ${ }^{15}$ a sus mujeres, aun cuando esto conllevaba una agresión física. ${ }^{16}$ Para Judith Bennett, esto se relaciona con el carácter jerárquico y estamental de la sociedad medieval, en donde el esposo era visto como un señor feudal: "Medieval people thought of conjugality as a hierarchy headed by a husband who not only controlled his wife's financial assets and public behavior, but also freely enforced his will through physical violence" (citado en Butler, 2006, p. 337). Lo mismo plantea Grossman en Pious and Rebellious cuando señala que "Medieval people -whether Christians, Muslims, or Jews -considered the wife as subjugated to her husband and 'under his hand"” (2004, p. 213).

Este poder casi absoluto que tenía el marido estaba en concordancia con las doctrinas y textos religiosos, lo que dificultaba que la mujer pudiese salir de esos círculos de violencia $^{17}$. En general los rabinos medievales sostuvieron que los maridos no debían golpear a sus esposas y, que de hacerlo, debían recibir un castigo (Grossman, 2004, p. 213), pero lo cierto es que en la práctica la realidad fue bastante distinta. En el texto mencionado antes, se alude al rabino José ibn Avitur ${ }^{18}$, para quien el maltrato hacia la esposa era una causa de divorcio, sin embargo, se debían cumplir dos requisitos para solicitarlo (Grossman, 2004, p. 218). La primera exigencia era que el marido ya hubiese recibido una advertencia sobre sus actos, es decir, que no fuese la primera vez que golpeaba a su mujer. Y el segundo requerimiento era que se necesitaba un testigo de los hechos violentos, condición que no favorecía a las mujeres.

También hallamos posiciones menos favorables, puesto que varias autoridades religiosas de la época asumieron que el marido podía golpear a la mujer para "corregirla". En torno a esto se afirma: "Many rabbis, like their Christian counterparts, assumed that it was a man's right and responsibility to beat his wife in order to correct

\footnotetext{
${ }^{15}$ Sobre este tema, véase Butler, 2007, p. 2.

${ }^{16} \mathrm{Si}$ bien no me detendré extensamente en torno a la violencia ejercida por los hombres hacia las mujeres en el Medioevo, sugiero algunas lecturas que me parecen indispensables. Véanse Goitein (1978), Grossman (1991), Bollo-Panadero (2007), Segura (2008) y Pallares (2010).

${ }^{17}$ Véase Classen, 2004, p. 17.

${ }^{18}$ Rabino nacido en Mérida, siglo X.
} 
her" (Taitz, 2003, p. 123). Por ejemplo, el rabino Šelomoh ben Adrat (Rashba) ${ }^{19}$ consentía que el hombre golpeara y castigara a su mujer en caso de que esta lo agrediera $^{20}$. Palabras similares hallamos en Maimónides: “Toda aquella mujer que intente no hacer alguno de los trabajos a los que está obligada, se le obliga incluso golpeándola con un látigo" (2010, p. 250).

Los casos de violencia de género tienen que haber sido numerosos, pues ya en la Baja Edad Media se empiezan a observar ciertas regulaciones al respecto. Por ejemplo, algunos tribunales judíos en los reinos cristianos de la Península ibérica sugirieron que si una mujer era golpeada constantemente y huía a casa de su padre, esta no podría ser considerada rebelde y además, "would not need to forfeit her ketubbah" (Taitz, 2003, p. 96), aunque no hay certeza de que esto se aplicara de manera oficial. Pese a que no había una ley en cada territorio que condenara la violencia hacia las esposas, en algunos casos sí se consideró la excesiva crueldad del maltrato como una forma de garantizarle a la mujer el divorcio ${ }^{21}$.

Sin embargo, y más allá de la comunidad religiosa en que estos hechos sucedieran, se puede inferir que la violencia física hacia las esposas era mucho más habitual que los casos que se conservan de la época, pues no todas las mujeres maltratadas denunciaban lo ocurrido, optando voluntariamente - $\mathrm{O}$ no- por el silencio. Como sostiene Fuente, "los casos que llegaban a los tribunales eran los realmente graves, pues cuando se trataba de pegar en un arrebato de ira, no se llevaba al marido a los tribunales y, por tanto, no se conoce esa clase de maltrato" (2006, p. 174). Este silencio es que el que se observa al final del relato El matrimonio, pues tras el ataque del marido, no se sabe más de su mujer. El protagonista se va lejos de la ciudad y es en ese momento cuando se encuentra con el narrador, volviendo al inicio del relato.

Sin duda, uno de los aspectos más llamativos es la reacción de Heman tras escuchar el relato del protagonista: "me reí de sus embustes y patrañas quedando sorprendido de sus ensueños y de sus palabras" (Al-Ḥarizi, 2010, p. 91

\footnotetext{
${ }^{19}$ Rabino español del siglo XIII.

${ }^{20}$ Véase Grossman, 1991, p. 57.

${ }^{21}$ Véase Hawkes 57-58.
} 
¿Se trata de restarle importancia a la violencia contra la esposa? Para Ross Brann, por ejemplo, se trataría de una estrategia textual para alivianar la brutalidad y el horror del cuento (2002, pp. 151-152). En mi opinión, se ridiculiza al protagonista, en cuanto se enamora de una mujer a la que nunca ha visto y se desespera por casarse lo antes posible. Este tono paródico se ve confirmado en la reacción de Heman tras escuchar el relato. Sin embargo, pese a esta caricatura que se hace del personaje masculino, hay son claros mecanismos misóginos en la configuración de los personajes femeninos, los que se analizarán en la cuarta sección de este artículo.

\section{La ofrenda de Judá el misógino de Yehudah ibn Šabbetay}

Otro autor que juega con el disfraz y el engaño femenino es Yehudah ibn Šabbetay (1168-principios del siglo XIII). Contemporáneo de al-Harizi, habría vivido en la España cristiana, aunque hay divergencias entre los investigadores sobre las ciudades ${ }^{22}$ en que habitó. Su obra más conocida es Minhat Yehudah śone ha-Našim (La ofrenda de Judá el misógino $)^{23}$, la que se habría compuesto en Toledo alrededor del año 1208.

La ofrenda de Judá el misógino "narra la historia de un hombre / cuya alma en trampa de mujer fue capturada” (Ibn Šabbetay, 2006, p. 53). Desde el primer momento se plasma una visión negativa sobre las mujeres. Esto ocurre cuando el padre del protagonista, Taḥkemoni, advierte a su hijo Zerah sobre la maldad de las féminas, que son retratadas como sembradoras de insidias y discordias, astutas, adúlteras y asesinas. Los varones, por otra parte, son descritos como víctimas de estas mujeres, jugando con citas y episodios bíblicos. Por ejemplo, se señala:

¡Cuántos hombres se convirtieron en oprobio y vergüenza a causa de la mujer! Juro por mí mismo que la serpiente no maquinó contra Eva ni le dio órdenes, fue ella quien convirtió a su marido en fugitivo de su ámbito. [...]

\footnotetext{
${ }^{22}$ Según Sáenz-Badillos y Huss, probablemente vivió en Toledo, Burgos y Zaragoza. V. Sáenz-Badillos, 1991, p. 207 y Huss, vol. I, 1991, p. 184.

${ }^{23}$ Se ha prescindido de las citas en hebreo para facilitar la lectura. El texto en hebreo se halla editado y anotado por Huss (1991).
} 
¿No fue a causa de Dina por quien hubo acusaciones contra su padre y sus hermanos? (Ibn Šabbetay, 2006, pp. 60-61)

El empleo de la Biblia como fuente de la cual valerse para censurar y desacreditar a las mujeres es un recurso bien conocido. No solo se aludían a fragmentos misóginos presentes en algunos libros del Antiguo Testamento como Proverbios o el Eclesiástico, sino que además se reproducían glosas bíblicas con un fuerte rechazo hacia las mujeres $^{24}$. Estas alusiones funcionaron como respaldos de autoridad en las construcciones de los discursos misóginos, siendo ejemplos conocidos y familiares para el receptor medieval, garantizando así su comprensión y difusión. Debemos recordar que el uso del intertexto bíblico no solo aparece en la literatura hispanohebrea, sino que es un fenómeno recurrente en la literatura latina y romance. ${ }^{25}$

Sin embargo, la estrategia textual de Ibn Šabbetay es algo contradictoria en el uso de los elementos bíblicos, ya que menciona a mujeres como Eva para condenar al género femenino, pero no alude a la Biblia cuando habla del matrimonio. Y es que en el Minhat Yehudah, Taḥkemoni -antes de morir- pide a su hijo que no se case, ya que "la fosa del matrimonio fue hecha para morir" (Ibn Šabbetay, 2006, p. 62).

El Judaísmo, por el contrario, promueve el matrimonio como un vínculo sagrado establecido en la Creación: "Por tanto, dejará el hombre a su padre y a su madre, y se unirá a su mujer, y serán una sola carne" (Génesis 2:24). Incluso, el celibato propuesto por Taḥkemoni ${ }^{26}$ dista bastante de las enseñanzas rabínicas sobre el tema, que lo condenan $^{27}$ : "Dijo el rabí Tanjum que dijo el rabí Janilái: El que no tiene esposa vive sin alegría $^{28}$, sin bendición y sin bien” (Yevamot 62b), el rabí Eleazar señala: "El que no

\footnotetext{
${ }^{24}$ Véase Archer, 2001, p. 21.

${ }^{25}$ La Biblia es uno de los principales textos que se usó como base para la construcción del discurso misógino medieval. Véase Archer, 2001, pp. 20-22. También véase Escartín (2007-2008).

${ }^{26}$ Tova Rosen se pregunta cómo el receptor medieval hubo de interpretar esta invectiva contra el matrimonio, siendo que era algo promovido y bien visto por los rabinos (2003, p. 107).

${ }^{27}$ Se condena el celibato, sin embargo, hay una serie de sentencias en contra de las mujeres, resaltando sus supuestos defectos. Véase Dishon (1994).

${ }^{28}$ Solo en algunas excepciones pareciera que el celibato tiene cabida, como es el caso del rabino Šim'on ben Azai (siglo II d.C.), que quería una vida solitaria para dedicarse a los estudios religiosos. En torno a este caso y al celibato en el Judaísmo, véase Horst (2002).
} 
tiene mujer no es hombre" (Yevamot 63a) y el rabí Jama bar Janiná dice al respecto: "No bien el hombre toma esposa terminan sus pecados" (Yevamot 63a).

Pero Tahkemoni no solo promueve el celibato de los varones, sino que plantea que el matrimonio es una maldición ${ }^{29}$, ya que según él, quien se case perderá su juventud y riqueza, llevando una vida de horrores. Por lo mismo, advierte a su hijo que no se case. Esta recomendación paterna continúa presente en la literatura de fines del Medioevo, como sucede en el Spill de Jaume Roig ${ }^{30}$. En este texto, el hablante lírico recomienda a su hijo que se aleje de las féminas y que solo recurra a la Virgen María:

Lo que te digo es, pues, que nunca te relaciones con las mujeres, ni te enredes con ellas para nada. Concuérdate sólo con la alta Madre que, junto a Dios Padre y el Espíritu Santo, de ellos emanante, tiene Hijo común que vive, único Dios, en unidad y en trinidad, eternamente (Roig, 2010, p. 180).

En el caso de Zerah, éste cumple la voluntad de su padre y junto a tres amigos decide irse lejos de la ciudad y llevar una vida célibe. Pero no solo pretende alejarse de las mujeres, sino que se burla de ellas y de todos aquellos que se han casado. Incluso va de visita a distintos pueblos instruyendo a los hombres que se alejen de sus esposas: "En cada ciudad donde la palabra y la fe de Zerah llegaban, de ajenjo y veneno a las mujeres hartaba" (Ibn Šabbetay, 2006, p. 69). Este comportamiento es la causa del engaño que aparece en el relato y que se analizará a continuación.

Debido a la actitud de Zerah, todas las mujeres se reúnen en una asamblea para decidir cómo detenerlo ${ }^{31}$, puesto que sus maridos se alejan continuamente de ellas y las jóvenes ya no encuentran pretendientes. De entre todas destaca Kozbi, quien no solo será la líder del grupo, sino también la alcahueta. Descrita como sabia, astuta y experta en brujerías, sus características son similares a las que hallamos en las descripciones de otras

\footnotetext{
${ }^{29}$ El tópico del varón que no debe tomar esposa se encuentra también en textos latinos medievales. Véase Rosen, 2003, p. 106.

${ }^{30}$ Véase Archer, 2001, p. 251.

${ }^{31}$ Para Tova Rosen esta representación de mujeres hablando sobre su sexualidad debió ser entretenido para una audiencia masculina, aunque también, debió resultar inquietante, puesto que implica una intromisión femenina en un discurso -el sexual- hegemónicamente masculino (2003, p. 110).
} 
alcahuetas como la anciana de El matrimonio de al-Harizi. Ella es quien planea enamorar a Zerah de una hermosa muchacha con la que querrá casarse. Sin embargo, esta será suplantada en el momento del matrimonio.

El retrato de cómo debe ser la joven sigue las convenciones de la literatura medieval mencionadas en el análisis previo. Por ejemplo, la muchacha debe ser hermosa y luminosa como el sol: "una muchacha de acabada belleza, perfecta, en la que no haya defecto alguno, que sea hermosa para todo el que la vea, que guste a todos los que la miren. Esclarecida como el sol” (Ibn Šabbetay, 2006, p. 71). Llama la atención que no solo se busca una joven de superlativas cualidades físicas, sino también oratorias y artísticas: la muchacha debe ser culta, educada, inteligente, poeta y hábil con el laúd y la nabla: "Que posea instrucción y consejo, que entienda los símiles y las metáforas, que hable con lenguaje exquisito y componga poemas, que sus dichos sean dulces como el panal de miel" (p. 71). Estamos ante un ideal femenino distinto, pues se entiende que la belleza ya no basta para disuadir a Zerah de su celibato, antes bien, se opta por quien tenga el don de la palabra, ya que solo así se podrá seducir al protagonista.

La joven que reúne todas las características y que realiza el simulacro es 'Ayyalah, de quien se dice que es la más perfecta de todas las mujeres. Ataviada con un vestido, joyas de oro y una corona, es presentada por Kozbi y su marido ante Zerah. Luego de verse por primera vez, lo más novedoso es que ella toma la palabra, y lo hace justamente para recitarle poemas ${ }^{32}$ a Zerah.

Pese a la promesa realizada a su padre, el protagonista decide casarse con esta joven. Se celebra entonces la fiesta de compromiso que dura siete días, aunque el novio parece estar en todo momento ausente: "Adquirieron de mano de Zerah una propiedad completa, pues estaba como sordo que no oye y como mudo" (Ibn Šabbetay, 2006, p. 86). Se lee además la ketubbah ${ }^{33}$, que aquí no es un texto solemne, sino una parodia ${ }^{34}$, en donde los testigos tienen nombres peyorativos, el novio ni siquiera firma el contrato y los regalos de los novios son desventuras que prefiguran lo que ocurrirá:

\footnotetext{
${ }^{32}$ Para Tova Rosen, los poemas que ella recita funcionan como un espejo en el que Zerah observa su reflejo, y como Narciso se enamora (2003, p. 112).

${ }^{33}$ Contrato matrimonial.

${ }^{34}$ Para un análisis detallado de esta escena, véase Fishman, 1988, p. 98.
} 
[Zerah] dio a ella en regalo estas cuatro cosas como presente: en lugar de vestidos grandes plagas, en lugar de anillos muchas y malas penas, en lugar de cinturón una cuerda, en lugar de perfumes podredumbre. Este es el ajuar que ha aportado la novia: vergüenza, horror, abominación y exterminio (Ibn Šabbetay, 2006, p. 85).

Es luego de esta lectura de la ketubbah y una vez que los desposados se hallan en la cámara que el simulacro queda en evidencia. La alcahueta Kozbi lleva a la esposa a la cámara de los novios. En ese espacio de intimidad, Zerah se da cuenta de que no se ha casado con 'Ayyalah sino con otra mujer, llamada Riṣpah y que destaca por su fealdad. Lo primero que se describe de ella es que se trata de una mujer tiránica, y luego se da paso a la descripción de su físico, mencionando lo oscuro de su piel. Junto con esto, el otro aspecto que se menciona es su calvicie. Esto último podría dar a entender que se trata de una mujer algo más vieja, en contraposición al ideal femenino que exaltaba las frondosas cabelleras de las damas como sinónimo de juventud.

Como era de esperar, una vez que se pone fin al simulacro, Zerah se muestra muy abatido y se rasga el vestido en señal de duelo. Sin embargo, lo notorio es que en vez de victimizarse culpando a Riṣpah, 'Ayyalah o Kozbi, él asume su parte de culpa: "Yo mismo me lo he cavado y a esta mujer he timado, no puedo, por tanto, hablar con dureza, ya que excavé este pozo y proporcioné a mi alma aquello que podía destruirla y devastarla" (Ibn Šabbetay, 2006, p. 87). En este sentido, notamos que su reacción dista bastante de aquella que se vio en El matrimonio, en donde el marido golpea brutalmente a su esposa por el engaño.

Tras conocerse el engaño, Rișpah tiene el poder de la palabra, increpando a Zerah y conminándolo a no ser rebelde, pues le ordena que le provea de vestidos, pendientes, perfumes y un sinfín de cosas. De hecho, lo amenaza, ya que si no cumple, la situación será peor. Notamos así un empoderamiento del personaje femenino que es capaz de callar textualmente al varón y hacerse con el dominio del discurso. 
Se observa por tanto, que 'Ayyalah y Riṣpah son mujeres activas que toman la palabra, pero mientras que la primera lo hacía para alabar a Zerah y mostrar una relación simétrica $^{35}$, la segunda lo hace precisamente para exigirle. Recordamos que esta última no solo le reclama cosas materiales, sino que también le ordena que se calle y deje de recitar poemas porque a ella no le gusta la instrucción, rasgo que como se vio anteriormente, fue primordial para que Zerah se enamorara de 'Ayyalah. De este control comunicativo ejercido por Riṣpah, se desprende que el matrimonio es presentado como "a semiotic battle over the domination of language and signification" (Rosen, 2003, p.113).

La reacción de Zeraḥ es similar a la de Heber en El matrimonio, ya que también huye de casa, aunque en el caso del primero, insiste en repudiar a su mujer y divorciarse de ella ${ }^{36}$. Aquí el autor introduce diversas opiniones sobre el repudio hacia la esposa: algunos hombres del pueblo le animan a tomar la decisión, mientras que otros lo disuaden. Pero el clamor general va más allá y son las mujeres quienes llegan al lugar para exigir justicia, rechazando el comportamiento del protagonista: "Guardad el derecho y practicad la justicia. Que no tengáis que sentir remordimientos. Que no se convierta Zerah en símbolo y ejemplo entre sus gentes. No podrá repudiarla en toda su vida" (Ibn Šabbetay, 2006, p. 95).

Finalmente, el rey Abraham se encarga de establecer el orden, condenando a Zerah no solo por repudiar a su mujer, sino por incitar a los demás varones del pueblo a rechazar a las suyas. La trama da luego un vuelco bastante llamativo, puesto que aparece en escena el autor: Yehudah ibn Šabbetay, en una estrategia metanarrativa que sorprende por su modernidad ${ }^{37}$. El autor se presenta para salvar a Zerah, su personaje, diciendo que todo ha sido una invención:

\footnotetext{
${ }^{35}$ Rosen señala que esta simetría entre 'Ayyalah y Zerah solo es posible como una fantasía erótica (2003, p. 113).

${ }^{36}$ Sobre el divorcio en las comunidades judías durante la Edad Media, véase Grossman, 2004, pp. 231239.

${ }^{37}$ Ciertamente existen casos de autores que aparecen como personajes en las obras medievales, como es el caso de Dante en la Divina Comedia, sin embargo, es difícil hallar ejemplos en donde el autorpersonaje se refiera a su obra como ficción y se exalte la metanarración.
} 
Ese Taḥkemoni no fue creado ni existió, ni se casó Zerạ̣ [...] Todas esas palabras no las pronunció nadie, pues son pura invención mía y sobre basas de plata se han vertido los cimientos. Más que todos los que me precedieron amo a mi mujer y a mis hijos. A fin de trocar el cariz de este asunto toda esta trama fue ensamblada para presentarla ante ti, para hallar gracia a tus ojos (Ibn Šabbetay, 2006, p. 97).

Estas palabras provocan la risa del rey y de los demás personajes-espectadores, que celebran el ingenio del autor, quien es finalmente recompensado por el rey.

\section{Mujeres feas, velludas y bestiales}

En los dos relatos analizados la configuración de los personajes femeninos se tiñe de un discurso misógino que busca retratar a estas mujeres como el epítome de la fealdad. Se trata de una fealdad construida mediante una serie de rasgos como su supuesta vellosidad, bestialidad y tono de la piel, características que buscan situar a estas mujeres en los márgenes de los cánones de belleza de la época, cimentando la visión negativa sobre ellas.

Con respecto a la presencia de vellos, de Riṣpah se dice que "ortigas le cubrían el rostro" (Ibn Šabbetay, 2006, p. 87) como una forma de masculinizarla. Contrasta así su rostro velludo (acaso barbuda), frente a las descripciones medievales que exaltan la tersura de la piel femenina ${ }^{38}$. De hecho, en el Libro de buen amor, don Amor aconseja cómo elegir a una mujer: "Guár[da]te que non sea bellosa ni barbuda: / ¡atal media pecada el huerco la saguda!" (Ruiz, 2012, p. 119).

\footnotetext{
${ }^{38}$ Un ejemplo de esto se halla en la descripción de la amada en el fabliau "De Guillaume au faucon", en el que se menciona que la dama "Le front avoit poli et plain, / Si com il fust fait à la mein" (la frente tenía tersa y sin arrugas, como si estuviese hecha a mano). Véase López Alcaraz, 2003, pp. 168-169. 
Esta asociación entre los vellos de las mujeres y su fealdad fue frecuente en la literatura medieval. Por ejemplo, el poeta Ausiàs March ${ }^{39}$ escribe:

Y no penséis que él os hubiera dejado una hija para que le dierais de mamar vuestra leche, pues vuestro cuerpo está repleto de veneno y lo muestran vuestros pelos desmedidos, porque si os dejáis crecer vuestra barba y os la cortáis, juntándola con los pelos de los brazos se podrían hacer espléndidas redes para atrapar perdices, tórtola o cogujada. (Archer y Riquer, 1998, pp. 226-227)

Estos retratos de mujeres velludas y que tanto se extendieron durante el Medioevo, quieren dar la idea de que estas mujeres se han masculinizado, restándoles feminidad. Es lo que ocurre, por ejemplo, en los relatos hagiográficos medievales en donde a determinadas santas - como Wilgefortis ${ }^{40}$ y Paula de Ávila ${ }^{41}$ - les crece la barba y/o vellos por todo el cuerpo, como una forma de adoptar una identidad masculina que les permita no casarse y proteger su virginidad, entre otros factores ${ }^{42}$. Pero también es lo que se observa en El matrimonio y los ejemplos antes citados, solo que esta pilosidad y rasgos masculinos van de la mano de otras nociones como la fealdad y monstruosidad.

La ausencia de belleza también se exacerbará por medio de imágenes bestiales. AlHarizi, por ejemplo, dice de la esposa que posee ojos de escorpión, equiparando a su mujer con un monstruo. ${ }^{43}$ Emplea así diversas imágenes de animales: sus labios son “como los belfos de un buey" (90), sus brazos son "peludos como los de un mono" (91)

\footnotetext{
${ }^{39}$ Poeta valenciano del siglo XV.

${ }^{40}$ La leyenda cuenta que Wilgefortis era una princesa convertida al cristianismo. Como su padre quería casarla a la fuerza, ella optó por rezar y ayunar prolongadamente hasta que un día le creció una larga barba. Como castigo, el padre decidió crucificarla. Para ahondar en torno a esta figura, véase Wallace (2014).

${ }^{41}$ Con respecto a Paula de Ávila, la historia popular cuenta que se trataba de una hermosa y piadosa muchacha que era perseguida por un joven galán. Un día la halló sola en una ermita, y ella -al ver que podría perder su honor- rezó a San Lorenzo para que la protegiera. Cuál no sería su sorpresa cuando una barba comenzó a crecerle, lo que alejó al hombre que la perseguía. Véase Valencia (2004).

${ }^{42}$ Con respecto a las santas velludas y barbudas, recomiendo el estudio de Vega (2008).

${ }^{43}$ Sobre el binomio “woman-monster”, véase Rosen, 2003, p. 12.
} 
y además, se refiere a la suciedad de su boca al increparla: "tus dientes son como inmundos dientes de osa" (90). Este recurso de asociar lo animal a las mujeres feas se halla también en el Libro de buen amor, cuando el protagonista describe a la serrana Alda: "mayor es que de osa la patada do pisa [...] / las orejas mayores que de añal burrico [...] / las sobrecejas anchas e más negras que tordos” (Ruiz, 2012, pp. 250-251).

Junto con la pilosidad y la bestialidad, el tercer rasgo que conforma esta fealdad se relaciona con el color de piel de estas mujeres. Por ejemplo, en El matrimonio se destaca especialmente que la esposa tiene una piel negra y que sus mejillas están hechas de carbón, tanto que el protagonista le dice: "tu figura es negra como tu fortuna" (AlHarizi, 2010, p. 91). Lo mismo se dice sobre el color de piel de Rișpah: "negra como el cuervo" (Ibn Šabbetay, 2006, p. 87). Este binomio negrura-fealdad es "uno de los atributos que con mayor reiteración se encuentran en la descripción de este tipo de personajes ya sea en obras escritas en árabe, hebreo o en cualesquiera de las lenguas románicas" (Salvatierra, 2013, p. 165), pues forma parte de la corriente misógina de la época.

Pero al-Ḥarizi e ibn Šabbetay van más allá: las mujeres no son solo feas, sino que por serlo, son además malas y demoníacas, imágenes recurrentes en textos literarios y sermones medievales ${ }^{44}$. Esto queda plasmado cuando Heber dice sobre su esposa:

de sus mejillas había huido la frescura, parecía como si el mismísimo Satanás las hubiera tiznado con la negrura y las hubiera trabajado con carbones. Llegué hasta a pensar que era una hija del infierno" (Al-Ḥarizi, 2010, p. 89). Lo anterior se refuerza cuando señala: “[Acaso] de demonios y brasas has sido forjada" (Al-Harizi, 2010, p. 90).

\footnotetext{
${ }^{44} \mathrm{Al}$ respecto se señala: "Like the devil, women were perceived as masking their perniciousness in attractive guises, and it was part of the exemplum's purpose to unveil their subtleties and sorceries in order to underscore the need for vigilance against them" (Gregg, 1997, p. 85).
} 
Este binomio de la mujer negra-demoníaca es frecuente en la literatura medieval ${ }^{45}$, como se halla en el Corbacho: "Fallan las gentes que Fulana es fermosa. ¡Oh Señor, y qué cosa es favor! Non la han visto desnuda como yo el otro día en el baño: más negra es que un diablo, [...] sus cabellos negros como la pez” (Martínez, 2011, p. 161).

También demoníaca es la descripción de la cuarta serrana en el Libro de buen amor:

En [e]l Apocalipsi Sant Johan Evangelista

non vido tal figura nin de tan mala vista;

a grand hato daría lucha e grand conquista:

non sé de quál diablo es tal fantasma quista. (Ruiz, 2012, p. 250)

En general, pareciera que este color se emplea en la retórica medieval para referirse a aquellos cuerpos femeninos que se sitúan al margen de los cánones de belleza establecidos ${ }^{46}$. En este sentido y como señala Aurora Salvatierra, habría una "reiteración del calificativo 'negro' como elemento inseparable de la imagen medieval de la fealdad" (615) y, según nuestro parecer, de lo monstruoso.

Esta asociación con lo negro no solo se empleó en los retratos de mujeres en la literatura medieval, sino en todo aquello que resultaba distinto, ya fuese en el ámbito religioso, racial, estético y/o de género. Esta otredad, que muchas veces era vista como anormal y peligrosa, se representó en los textos del Medioevo, tiñéndose de rasgos bestiales, monstruosos e incluso, malignos ${ }^{47}$. Así lo evidenciamos en algunas descripciones de los enemigos de Carlomagno en la Chanson de Roland, de la princesa Amiete que venga la muerte de su marido en el poema épico Fierabras y, la representación de Lujuria como una mujer fea y negra en la Disciplina Clericalis de Pedro Alfonso, solo por mencionar algunos ejemplos.

\footnotetext{
${ }^{45}$ Esto también se encuentra en el arte. Basta apreciar imágenes como un detalle de la "Tebaide" (cuya fecha aproximada es 1343), en donde el diablo adquiere la imagen de una joven peregrina. Véase Frugoni (1992).

${ }^{46}$ Además del color, en el caso de Ibn Šabbetay se asocia la mujer al cuervo, ave que aparece frecuentemente en la tradición hebrea como símbolo de eventos desafortunados. En torno a esto véase Melamed, 2003, p. 48.

${ }^{47}$ Debemos recordar que en la Edad Media la imagen de Satanás se asoció generalmente al color negro. Véanse Weever, 1998, p. ix y Melamed, 2003, p. 151.
} 
La asociación de la fealdad con la falta de virtudes y maldad fue ampliamente compartida en el Medioevo, época en la que lo bello era entendido como un valor, como algo bueno y verdadero, mientras que lo feo era percibido como una corrupción de la Naturaleza y, por ende, era defectuoso, malo e incluso, demoníaco. Como sostiene Montserrat Cabré (2010): "Western cultures conceived beauty as the aesthetic aspect of pleasure and the good; in contrast, ugliness embodied aversion but also wickedness" (p. 129).

Por lo mismo, ni Zerah ni Heber están dispuestos a soportar a mujeres feas y, por ende, malas. En este sentido, concuerdo con Patrizia Bettella cuando sostiene que la mujer fea, al no formar parte del canon de belleza, escapa del control y desafía el orden social. Se trata de un tipo de mujer que desestabiliza el orden imperante y, por ende, resulta peligrosa. De ahí que sea excluida o castigada.

\section{Consideraciones finales}

Después del análisis realizado, es necesario preguntarse si acaso las dos obras estudiadas son misóginas o si el tono paródico contribuye a "suavizar" el discurso hacia las mujeres.

Por una parte, los textos discutidos refuerzan la idea de que las mujeres engañan por medio de la palabra, como se vio en los casos de las alcahuetas. Si a esto le sumamos la presencia de mujeres feas y, por ende, peligrosas, se está ante un escenario que debió resultar al menos inquietante para un público medieval, que veía la supuesta "amenaza" de estas mujeres como algo próximo y cercano. A lo anterior se añade la violencia de la que es víctima la esposa en el relato de al-Harizi, pues es silenciada textualmente y reprendida por un engaño que nunca ideó.

Por otro lado, se critica la falta de juicio y el atolondramiento de los varones, ridiculizando sus comportamientos. Además, en los finales de ambos relatos los personajes que oyen lo sucedido se ríen de lo narrado. En El matrimonio Heman se ríe 
de los embustes del protagonista, y en La ofrenda de Judá tanto el monarca como los otros espectadores celebran festivamente el ingenio del autor que ha aparecido en escena. Debido a estos desenlaces hay quienes plantean que los mensajes misóginos de las obras no serían tales.

Según mi parecer, más allá del humor presente en los relatos y el hecho de que otros personajes se rían en última instancia de los protagonistas y algunas de sus exageraciones, de igual manera aparecen hechos de violencia hacia las mujeres, los que no pueden dejarse al margen. Concuerdo en este sentido con Tova Rosen, para quien el humor funciona como una estrategia ideológica y que, por lo mismo, si el texto se propone divertir, esto “does not necessarily mitigate antifeminism” (2003, p. 117).

Ahora bien, en los textos estudiados se produce una dialéctica entre los retratos más favorables hacia las mujeres y los mecanismos misóginos. Por ejemplo, se muestra que ellas se adueñan de los espacios enunciativos, pueden idear planes, organizar a un grupo de mujeres y obtener provecho de sus engaños en algunos casos. Estas imágenes están en permanente diálogo con esa fealdad femenina que tanto aterra y desprecian los varones.

Para concluir, a lo largo de este trabajo se han analizado las suplantaciones y engaños femeninos presentes en los relatos de al-Ḥarizi e ibn Šabbetay. Se ha descrito y estudiado cómo se configuran las representaciones de las mujeres, la asociación de las mujeres feas con lo monstruoso y las reacciones masculinas frente a esa otredad. El estereotipo de la fealdad se erige como una forma más que trata de silenciar la presencia femenina en la literatura medieval.

\section{OBRAS CITADAS}


Al-Harizi, Y. (1998). "El matrimonio". En Carlos del Valle Rodríguez (trad. y ed.). Las asambleas de los sabios (Tahkemoni), pp. 86-91. Murcia: Universidad.

. (2010). "Ha-niśśu 'im". En Tahkemoni or The Tales of Heman the Ezrahite, pp. 357-

365. Y. Yahalom y N. Katsumata (eds.). Jerusalén: Ben-Zvi Institute for the Study of Jewish Communities in the East. [En hebreo].

Alvar, C. (1984). El Dolce Stil Novo. Antología. Madrid: Visor.

Archer, R. (2001). Misoginia y defensa de las mujeres. Madrid: Cátedra.

e I. de Riquer. (1998). Contra las mujeres: Poemas medievales de rechazo $\quad y$ vituperio. Barcelona: Quaderns Crema.

Bettella, P. (2005). The Ugly Woman. Toronto: UP.

Bloch, A (1980). The Biblical and Historical Background of Jewish Customs and Ceremonies. Nueva York: KTAV Publishing House.

Boccaccio, G. (1982). El Decamerón. Trad. Marcial Olivar. Barcelona: Planeta.

Bollo-Panadero, M. D. (Otoño 2007). "El soporte ideológico de la violencia de género en la narrativa medieval ibérica". Confluencia 23(1), 2-9.

Brann, R. (2002). Power in the portrayal. Nueva Jersey: Princeton UP.

Butler, S. (Invierno 2006). "Runaway Wives: Husband Desertion in Medieval England", Journal of Social History 40(2), 337-359.

Butler, S. (2007). The Language of Abuse. Marital Violence in Later Medieval England. Leiden: Brill.

Cabré, M. (2010). "Beautiful Bodies". En L. Kalof (ed.). A Cultural History of the Human Body in the Middle Ages (pp.127-148). Nueva York: Berg.

Chaucer, G. (2011). "El cuento de la comadre de Bath". En P. Guardia Massó (trad.). Cuentos de Canterbury (pp. 221-230). Madrid: Cátedra.

Classen, A. (2004). "Introduction". En A. Classen (ed.). Violence in Medieval Courtly literature (1-36). Nueva York: Routledge.

Decter, J. (2007). Iberian Jewish Literature: Between al-Andalus and Christian Europe. Indiana: Bloomington UP.

Dishon, J. (1994). "Images of Women in Medieval Hebrew Literature". En J. Baskin (ed.). Women of the Word: Jewish Women and Jewish Writing (pp. 35-49). Michigan: Wayne State UP.

Duby, G. (1998). Damas del siglo XII. Eva y los sacerdotes. Madrid: Alianza.

Escartín Gual, M. (2007-2008). "Pandora y Eva: la misoginia judeo-cristiana y griega en la literatura medieval catalana y española". Revista de Lenguas y Literaturas Catalana, Gallega y Vasca, 19, 55-71. 
Fishman, T. (1988). “A Medieval Parody of Misogyny: Judah ibn Shabbetai's Minhat Yehudah sone hanashim”. Prooftexts 8, 89-111.

Frugoni, C. (1992). "La mujer en las imágenes, la mujer imaginada". En G. Duby y M. Perrot (eds.). Historia de las mujeres, vol. 4 (pp. 34-83). Madrid: Taurus, 1992.

Fuente, M. J. (2006). Velos y desvelos: Cristianas, musulmanas y judías en la España medieval. Madrid: La esfera de los libros.

Goitein, S. D. (1978). A Mediterranean Society. The Family, vol. III. Berkeley: California UP.

Gregg, J. (1997). Devils, Women and Jews. Reflections of the Other in Medieval Sermon Stories. Albany: State University of New York Press.

Grossman, A. (Primavera 1991). "Medieval Rabbinic Views on Wife-Beating, 800-1300", Jewish History 5(1), 53-62.

Brandeis UP.

(2004). Pious and Rebellious: Jewish Women in Medieval Europe. Massachusetts:

Hamilton, M. (2007). Representing Others. Nueva York: Palgrave.

Haro, M. (1995). "De las buenas mujeres". En J. Paredes (coord.). Medioevo y Literatura. Actas del V Congreso de la Asociación Hispánica de Literatura Medieval (Granada, 27 septiembre 1 octubre 1993). Volumen II (pp. 457-476). Granada: Universidad.

Hawkes, E. (2002). "The 'Reasonable' Laws of Domestic Violence in Late Medieval England". En E. Salisbury y otros (eds.). Domestic Violence in Medieval Texts (pp. 57-70). Florida: University Press of Florida.

Horst, P. van der. (2002). "Celibato en el Judaísmo Antiguo”. Sefarad 62(1), 85-98.

Huss, M. (1991). "Critical Editions of Minhat Yehudah, Ezrat Hanashim and 'Ein Mishpat with Prefaces, Variants, Sources and Annotations", vols. I y II. Tesis doctoral, Universidad Hebrea de Jerusalén, [en hebreo].

Ibn Hazm, A. (2009). El collar de la paloma. J. Sánchez Ratia (ed. y trad.). Madrid: Hiperión.

Ibn Šabbetay, Y. (2006). La ofrenda de Judá el misógino. Á. Navarro Peiro (ed. y trad.). Granada: Universidad.

Isaacs, R. (2000). “Ostrich”. En Animals in Jewish Thought and Tradition (pp. 27-28). Nueva Jersey: Aronson.

Leech, E. (2002). "The Rhetoric of the Body: A Study of Body Imagery and Rhetorical Structure in Medieval Literature". Tesis doctoral, Universidad de Cincinnati.

López Alcaraz, J. (2003). "De Guillaume au faucon”. En J. López Alcaraz (ed. y trad.). Los Fabliaux III (pp. 166-180). Murcia: Universidad.

Louzada, P. (2010). "Difamación y defensa de la mujer en la Edad Media. Pasajes obligatorios". Temas medievales 18, 73-94.

Maimónides. (2010) Leyes sobre el matrimonio (Hilkot Ishut) del Mishné Torá. O. Ruiz Morell y A. Salvatierra Ossorio (eds. y trads.). Pamplona: Editorial Verbo Divino. 
Martínez de Toledo, A. (2011). Arcipreste de Talavera o Corbacho. M. Gerli (ed.). Madrid: Cátedra.

Melamed, A. (2003). The Image of Black in Jewish Culture. B. Sigler Rozen (trad.). Londres: Routledge.

Olalla Sánchez, M. (2002). "El legado cultural de los judíos en España”. En S. Catalá y otros (coords.). Judaísmo, Sefarad, Israel (pp. 81-98). Cuenca: Universidad de Castilla-La Mancha.

Pallares, M. C. (2010). "Conciencia y resistencia. La denuncia de la agresión masculina en la Edad Media”. En R. Radl (coord.). Investigaciones actuales de las mujeres y del género (pp. 177-198). Universidad de Santiago de Compostela: Universidad.

Pizán, C. de. (2013). La ciudad de las damas. M. J. Lemarchand (ed. y trad.). Madrid: Siruela.

Psaki, R. (2003). "Women Make All Things Lose Their Power: Women's Knowledge, Men's Fear in the Decameron and the Corbaccio". Heliotropia 1(1), 1-13.

Reina, M. F. (Ed). (2007). Poesía andalusí. Madrid: Edaf.

Roig, J. (2010). El Espejo o Libro de las mujeres. A. I. Peirats (ed. y trad.). Madrid: Centro de Lingüística Aplicada Atenea.

Rosen, T. (2000). "Sexual Politics in a Medieval Hebrew Debate", Exemplaria 12,1, 157-184. . (2003). Unveiling Eve: Reading Gender in Medieval Hebrew Literature. Filadelfia: U of Pennsylvannia P.

Ruiz, J. (2012). Libro de buen amor. A. Blecua (ed.). Madrid: Cátedra.

Sáenz-Badillos, Á. (1991). Literatura hebrea en la España medieval. Madrid: Fundación Amigos de Sefarad.

Almendro.

y J. Targarona (1988). Diccionario de autores judíos: Sefarad, siglos X-XV. Córdoba: El

Salvatierra Ossorio, A. (2013) “'Negra como el cuervo': la 'estética' de la fealdad en textos hebreos de la Iberia Medieval”. eHumanista 23, 605-621.

Segura, C. (2008). "La violencia sobre las mujeres en la Edad Media", Clío \& Crimen 5, 24-38. Taitz, E., S. Henry y C. Tallan. (2003). JPS Guide to Jewish Women. Filadelfia: The Jewish Publication Society.

Tanenbaum, A. (2002). Contemplative Soul: Hebrew Poetry and Philosophical Theory in Medieval Spain. Leiden: Brill.

Valencia, M. de los A. (2004). Simbólica femenina y producción de contextos culturales. El caso de Santa Barbada. Ávila: Diputación de Ávila.

Vega, C.A. (2008). El transformismo religioso. La abnegación sexual de la mujer en la España medieval. Madrid: Pliegos. 
Victorio, J. (1986). "La mujer en la épica castellana". En Y. R. Fonquerne y A. Esteban (coords.). La condición de la mujer en la Edad Media (pp. 75-84). Madrid: UCM.

Wacks, D. (2007). "Social Change, Misogyny, and the Maqāma in Jaume Roig's Spill". En Framing Iberia (pp. 194-235). Leiden: Brill.

Wallace, L. (Primavera 2014). "Bearded Woman, Female Christ: Gendered Transformations in the Legends and Cult of Saint Wilgefortis". Journal of Feminist Studies in Religion 30(1), 4363.

Weever, J. de. (1998). Sheba's Daughters: Whitening and Demonizing the Saracen Woman in Medieval French Epic. Londres: Routledge.

Ziolkowski, J. (Enero 1984). "Avatars of Ugliness in Medieval Literature". The Modern Language Review 79(1), 1-20. 